\title{
Editorial
}

\section{Ebola and other issues in the health sector in Africa}

\author{
JK Tumwine
}

Department of Paediatrics and Child Health, College of Health Sciences, MakererebUniversity

In this September issue of African Health Sciences we bring you diverse articles with wide ranging themes. In general, they encompass infectious disease, glucose metabolism, newborn care, non communicable diseases and health systems.

We have added a special article[1] on viral hemorrhagic fevers especially Ebola, since this epidemic is ravaging the West African region.[2] In this article Uganda Ministry of Health and WHO workers describe their experience with the control of Ebola, and draw out some very specific lessons which the West African Ministries of Health might wish to adopt. This at a time when Liberian, Ugandan and other doctors working in West Africa have succumbed to the disease while carrying out the gallant duty of saving lives of those inflicted by Ebola. It is like déjà vu because it is not so long ago since Lukwiya, Kule and Mutooro - those highly dedicated Ugandan doctors, died after caring for Ebola patients. Lukwiya and Kule died in Uganda while Mutooro succumbed only recently in West Africa.

Now back to glucose. In a randomized controlled trial, Kutamba et al[3] determined the efficacy of dextrose infusion by burettes versus 2 hourly dextrose boluses in the prevention of hypoglycaemia among pre-terms in Kampala. The continuous 10\% dextrose infusion by burettes reduced hypoglycaemia episodes by $81 \%$. Kenyan workers on the other hand studied hypoglycaemia and hypocalcaemia as determinates of birth weight criteria for term stable low risk macrocosmic neonates. [4] Neonatal mortality is a big issue accounting for over $60 \%$ of child deaths worldwide. Cameroonian workers report a steady decline of neonatal mortality with asphyxia, sepsis and prematurity the major culprits.[5] When will our children stop dying?

Now: to glycosylated haemoglobin (HbA1C). Is it associated with diabetic ketoacidosis (DKA)? South African scientists [6] report this association in a paper on DKA in newly diagnosed type 2 diabetes, while Turkish workers found that high HbA1C levels in obese children can be used to screen for insulin sensitivity.[7] Keeping with the diabetes theme, Gangwar et al studied the impact of medication and psychological behaviour assessment by community pharmacists in type 2 diabetes mellitus patients after hospital stay. [8]

From diabetes to physical fitness: aerobic exercise training modulates inflammatory cytokine levels/markers of liver function in patients with non alcoholic steatohepatitis, report Saudi researchers. [9] On the other hand Sengupta et al found that tea growers in West Bengal were physically fit but with poor BMI and waist hip ratio.[10] Chinese workers[11] provide evidence of the influence of bakuchiol on drug metabolism through inhibition of UDP-glucuronosyltransferasee (UGT) 2 B7.

Fast wind to obesity: is neck circumference an indicator of obesity? So it seems from work by Turkish scientists. [12] Chopera's work on food labelling reading and understanding in rural and urban Zimbabwe scratches the surface on this theme of non communicable disease: a recurrent or rather chronic theme in African Health Sciences. We follow it with an interesting report on innovative methods for removing bacteria from surfaces in convenience food manufacturing plants[13].

Risk of high blood pressure among bankers and traffic wardens,[14] CVD risk factors[15], acquired heart disease in children in Nigeria[16] - now Africa's largest economy[17]; severe valvular dysfunction among rheumatic heart diseases patients in Uganda[18] give an interesting taste of what we shall continue seeing regarding cardiovascular disease in Africa.[19]

Have you heard about tolerogenic dentritic cells? What about the Decoy method? Just look up this article.[20] Eggs and chicken are popular worldwide but allergy is a real issue. Saudi scientists report on their work on screening for hen's egg and chicken meet specific antibodies in their patients with allergic disorders.[21]; while others report on the isolation, purification and efficacy of psoralen and isopsoralen in the treatment of osteosarcoma.[22] Papers on acute lung injury[23], prostate cancer pathogenesis[24] conclude this treatise on non communicable diseases.

As expected in LMICs, infections abound, and that is why we have prefaced this article with Ebola.[1] Is screening immigrants for TB on arrival from low to prevalent countries cost effective?[25] What about 
Chlamydia and infertility?[25] Or what is the basis of selection of first and second line HARRT?[26] You will get some answers by perusing these articles. The rest of the articles are on acute kidney injury amongst neonates with perinatal asphyxia,[27] use of ultrasound,[28] management of low back pain, [29] organophosphate poisoning[30], asthma exacerbations[31], thoracic surgery[32], dopamine[33], glaucoma in Ghana[34], dentistry[35], Chinese medicine[36], herbs and MRSA[37]. We continue with health research in Africa[38], Coats'disease[39], seasonal ataxia[40], rupture of the middle colic artery[41], neurofibromas[42], and the habit of eating stray dog meat[43] that refuses to go away. Have nice reading.

James K Tumwine

Cite as: Tumwine JK. Ebola and other issues in the health sector in Africa. Afr Health Sci 2014, 14(3): i-iv References:

1. Mbonye AK, Wamala JF, Nanyunja M, Opio A, Makumbi I, Aceng JR: Ebola Viral Hemorrhagic Disease Outbreak in West Africa- Lessons from Uganda. Afr Health Sci 2014, 14(3).

2. Baize S, Pannetie D, Oestereich L, Rieger T, Koivogui L, Magassouba N, Gunther S: Emergence of Zaire Ebola virus disease in Guinea - Preliminary report. The New England Journal of Medicine 2014, doi/full/10.1056/NEJMoa1404505.

3. Kutamba E, Lubega S, Mugalu J, Ouma J, Mupere E: Dextrose boluses versus burette dextrose infusions in prevention of hypoglycemia among pre-terms admitted at Mulago Hospital: an open label randomized clinical trial. Afr Health Sci 2014, 14(3):495-502.

4. Bandika VL, Were FN, Simiyu ED, Oyatsi DP: Hypoglycaemia and hypocalcaemia as determinants of admission birth weight criteria for term stable low risk macrosomic neonates. Afr Health Sci 2014, 14(3):503509.

5. Mungyeh ME, Chiabi A, Tchokoteu PFL, Nguefack S, Bogne JB, Siyou H, Soh FF, Mbonda E, Tchokoteu PF: Neonatal mortality in a referral hospital in Cameroon over a seven year period: trends, associated factors and causes. Afr Health Sci 2014, 14(3):510518.

6. Chukwuma E, Longo-Mbenza B, Blanco-Blanco E: Glycosylated haemoglobin is markedly elevated in new and known diabetes patients with hyperglycaemic ketoacidosis in South Africa. Afr Health Sci 2014, 14(3):519-525.

7. Önal ZE, Atasayan V, Gürbüz T, Hepkaya E, Nuhoğlu C: Association of glycosylated hemoglobin (HbA1c) levels with insulin resistance in obese children in Turkey. Afr Health Sci 2014, 14(3):526-531.

8. Gangwar SS, Monisha N, Nachiya J, Narasingarao K, Parimalakrishnan S, Singh SP: Impact of medication and psychological behaviour assessment by community pharmacists in type 2 diabetes mellitus patients after hospital stay: a randomized controlled trial. Afr Health Sci 2014, 14(3):532-543.

9. Shehab M, Abd E, Osama HA, Fadwa MA: Markers of liver function and inflammatory cytokines modulation by aerobic versus resisted exercise training for nonalcoholic steatohepatitis patients. . Afr Health Sci 2014, 14(3):544-550.

10. Sengupta P, Sahoo S: Health-related morphological characteristics and physiological fitness in connection with nutritional, socio-economic status, occupational workload of tea garden workers. Afr Health Sci 2014, 14(3):551-556.

11. Yu X, Peizhong L, Zhang X, Wang J, Dongsheng $G$, Wang Y: In vitro evidence for bakuchiol's influence towards drug metabolism through inhibition of UDP-glucuronosyltransferase (UGT) 2B7. Afr Health Sci 2014, 14(3):557-562.

12. Saka M, Perim T, Aydan E, Kiziltan G, Murat $B$ : Is neck circumference measurement an indicator for abdominal obesity? A pilot study on Turkish Adults. . Afr Health Sci 2014, 14(3):563-568.

13. Lambrechts AA, Human IS, Doughari JH, Lues JFR: Efficacy of low-pressure foam cleaning compared to conventional cleaning methods in the removal of bacteria from surfaces associated with convenience food. Afr Health Sci 2014, 14(3):578-585.

14. Salaudeen AG, Musa OI, Babatunde OA, Atoyebi OA, Durowade KA, Omokanye LO: Knowledge and prevalence of risk factors for arterial hypertension and blood pressure pattern among bankers and traffic wardens in Ilorin, Nigeria. . Afr Health Sci 2014, 14(3):586592.

15. Odunaiya NA, Louw QA, Grimmers- Somers K, Okechukwu SO: Development, initial content validation and reliability of Nigerian Composite Lifestyle CVD risk factors questionnaire for adolescents. Afr Health Sci 2014, 14(3):593-601.

16. Sadoh EW, Uzodimma CC, Daniels Q: Childhood acquired heart disease in Nigeria: an echocardiographic study from three centres. Afr Health Sci 2014, 14(3):602-609.

17. Presto H: Nigeria's suddenly supersized economy is indeed a wonder; but so are its still-huge problems. The Economist 2014(April 2014).

18. Lubega S, Aliku T, Lwabi P: Echocardiographic pattern and severity of valve dysfunction in children with rheumatic heart disease seen at Uganda Heart In- 
stitute, Mulago hospital. Afr Health Sci 2014, 14(3):610618.

19. Gersh BJ, Sliwa K, Mayosi BM, Yusuf S: The epidemic of cardiovascular disease in the developing world: global implications. European Heart Journal 2010, 31:642-648

20. HongMei J, YaLi Z, XiangFei Y, HengGui H, XiaoLei H, Ying F, Yanyang T, Zhang Y: Construction and evaluation of rats' tolerogenic dendritic cells (DC) induced by NF-xB Decoy method Afr Health Sci 2014, 14(3):619-626.

21. Shakoor Z, Adel A, Rana M, Waleed H, Bushra $Z$ : Screening for hen's egg and chicken meat specific $\mathrm{IgE}$ antibodies in Saudi patients with allergic disorders. Afr Health Sci 2014, 14(3):627-633.

22. Honghui L, Lihai Z, Daohong L, Peifu T, Feixiang S: Isolation and purification of psoralen and isopsoralen and their efficacy and safety in the treatment of osteosarcoma in nude rats. Afr Health Sci 2014, 14(3):634-640.

23. Binjian L, Xin L, Chaoling Q, Shuhui Z, Muxiu Z, Jianmin W, Wen Y: KGFR promotes $\mathrm{Na}+$ channel expression in a rat acute lung injury model. Afr Health Sci 2014, 14(3):641-649.

24. Naidu N, Botha JH, Naidoo S: B1 but not B2 bradykinin receptor agonists promote DU145 prostate cancer cell proliferation and migration Afr Health Sci 2014, 14(3):650-655.

25. Sammeh A, Alsharif M: Effectiveness and cost of screening immigrants for tuberculosis (TB) on arrival from high endemic to low prevalent countries: a systematic review. Afr Health Sci 2014, 14(3):656-664.

26. Katusiime C, Ocama P, Kambugu A: Basis of selection of first and second line highly active antiretroviral therapy for HIV / AIDS on genetic barrier to resistance: a literature review. Afr Health Sci 2014, 14(3):672674.

27. Alaro D, Bashir A, Musoke R, Wanaiana L: Prevalence and outcomes of acute kidney injury in term neonates with perinatal asphyxia. Afr Health Sci 2014, 14(3):675-681.

28. Eze C, Okoye J, Agwu K: Normative ultrasound values of renal parenchymal thickness among adults in Enugu, South-East Nigeria. . Afr Health Sci 2014, 14(3):682-690.

29. Major-Helsloot ME, Crous CL, Grimmer-Somers K, Louw QA: Management of LBP at primary care level in South Africa: up to standards? Afr Health Sci 2014, 14(3):691-699.

30. Wiwanitkit V: Acute organo-phosphorus pesticide poisoning, oxidative damage, haemoglobin level and total leukocyte (letter). Afr Health Sci 2014, 14(3):700. 31. Sanya RE, Kirenga BJ, Worodria W, OkotNwang M: Risk factors for asthma exacerbation in patients presenting to an emergency unit of a national referral hospital in Kampala, Uganda. Afr Health Sci 2014, 14(3):701-709.

32. Yi-Jiang H, Mao-Xiu P, Shao-Qi H, Liang-Le L, Ming-Hai D, Chenxuan T: Biomechanical study of the funnel technique applied in thoracic pedicle screw replacement. . Afr Health Sci 2014, 14(3):710-718.

33. Jin $G$, Xin-Rong H, Li-Ping C: The protective effect of Ginko bilboa leaves injection on the brain dopamine in the rat model of cerebral ischemia/reperfusion injury Afr Health Sci 2014, 14(3):719-722.

34. Francis AW, Gyasi ME, Adjuik M, Kesse E, Yifan C, Rhys SRH, Kodjo RA: Comparison of Primary Open Angle Glaucoma Patients in Rural and Urban Ghana. . Afr Health Sci 2014, 14(3):723-729.

35. Alsakran AM: Update knowledge of dry mouth - a guideline for dentists Afr Health Sci 2014, 14(3):730736.

36. Jian Z, Xin N, Xue-zhi Y, Qing-wen Z, Hai-yan L, Xuan W, Zhi-guo Z, Hong S: Design and application of pulse information acquisition and analysis system with dynamic recognition in traditional Chinese medicine. . Afr Health Sci 2014, 14(3):737-746.

37. Coulibaly K, Zirihi G, Guessennd-Kouadio N, Oussou KR, Dosso M: Antibacterial properties studies of trunk barks of Terminalia ivorensis (Combretaceae), a commercial and medicinal specie, on some methicillin-resistant Staphylococci spp strains. . Afr Health Sci 2014, 14(3):747-750.

38. Onyeka IN: Health research in Africa: are we communicating our findings to relevant stakeholders? Afr Health Sci 2014, 14(3):751-756.

39. Rugwizangoga B, Mwabili T, Scanlan T, Meyer P, Kitinya J: Coats' disease in Tanzania: first case report and literature review. Afr Health Sci 2014, 14(3):757762.

40. Adebiyi AM, Fawale MB, Adeyoyin KM, Nnaemeka AV, Oluwatoyin G, Oladeji AV: Seasonal ataxia: a case report of a disappearing disease Afr Health Sci 2014, 14(3):763-765.

41. Randawa AJ, Ajayi V, Albert S: Spontaneous rupture of the middle colic artery resulting in delayed postpartum collapse: a case report. . Afr Health Sci 2014, 14(3):766-767.

42. Ugare G, Omotosho J, Okon C, Bassey C: Neurofibromas as bilateral cystic chest wall swellings. Afr Health Sci 2014, 14(3):768-770.

43. Wiwanitkit V: Stray dog meat consumption and rabies - letter. Afr Health Sci 2014, 14(3):771. 